\title{
Classification Scheme
}

1. Structure of Crystalline Solids

1.1 Perfectly Periodic Structure

1.2 Solid-State Phase Transformations

1.3 Alloys. Metallurgy

1.4 Microstructure (Magnetic Domains See 18; Ferroelectric Domains See 14.4.1)

1.5 Films

1.6 Surfaces

2. Non-Crystalline State

3. Crystal Growth

4. Bonding Properties

5. Mössbauer Spectroscopy

6. Lattice Dynamics. Phonons

7. Acoustic Properties

8. Thermal Properties

9. Diffusion

10. Defect Properties (Irradiation Defects See 11)

10.1 Metals

10.2 Non-Metals

11. Irradiation Effects (X-Ray Diffraction Investigations See 1 and 10)

12. Mechanical Properties (Plastic Deformations See 10)

12.1 Metals

12.2 Non-Metals

13. Electron States

13.1 Band Structure

13.2 Fermi Surfaces

13.3 Surface and Interface States

13.4 Impurity and Defect States

13.5 Elementary Excitations (Phonons See 6)

13.5.1 Excitons

13.5.2 Plasmons

13.5.3 Polarons

13.5.4 Magnons

14. Electrical Properties. Transport Phenomena

14.1 Metals. Semi-Metals

14.2 Superconductivity. Superconducting Materials and Devices

14.3 Semiconductors

14.3.1 Films

14.3.2 Surfaces and Interfaces

14.3.3 Devices. Junctions (Contact Problems See 14.3.4)

14.3.4 High-Field Phenomena, Space-Charge Effects, Inhomogeneities, Injected Car-

14.4 Dielectrics riers (Electroluminescence See 20.3; Junctions See 14.3.3)

14.4.1 Ferroelectrics

15. Thermoelectric and Thermomagnetic Properties

16. Photoconductivity. Photovoltaic Effects

17. Emission of Electrons and Ions

17.1 Field Emission Microscope Investigations

18. Magnetic Properties

18.1 Paramagnetic Properties

18.2 Ferromagnetic Properties

18.2.1 Ferromagnetic Films

18.3 Ferrimagnetic Properties

18.4 Antiforromagnetic Properties 


\title{
physica status solidi (a) applied research
}

\author{
Board of Editors
}

S. A MELINCKX, Mol-Donk, J. AUTH, Berlin, H. BETHGE, Halle, K. W. BÖER, Newark, P. GÖRLICH, Jena, G. M. HATOYAMA, Tokyo, C. HI LSUM, Malvern, B. T. KOLOMIETS, Leningrad, W. J. MERZ, Zürich, A. SEEGER, Stuttgart, G. SZIGETI $\dagger$, Budapest, K. M. VAN VLIET, Montréal

$$
\begin{gathered}
\text { Editor-in-Chief } \\
\text { P. GöRLICH }
\end{gathered}
$$

Advisory Board

L. N. ALEKSANDROV, Novosibirsk, W. ANDRÄ, Jena, E. BA UER, Clausthal-Zellerfeld, G. CHIAROTTI, Rom, H. CURIEN, Paris, R. GRIGOROVICI, Bucharest, F. B. HUMPHREY, Pasadena, E. KlIER, Praha, Z. MÁlE K, Praha, G. O. MUUlleR, Berlin, Y. NAKAMURA, Kyoto, T. N. RHODIN, Ithaca, New York, R. SIZMANN, München, J. STUKE, Marburg,

J. T. WALLMARK, Göteborg, E. P. WOHLFARTH, London

Volume 55 - Number 2 Pages 341 to 810 , K131 to K210, and A9 to A16

October 16, 1979

PSSA 55(2) 341-810, K131-K210, A9-A16 (1979)

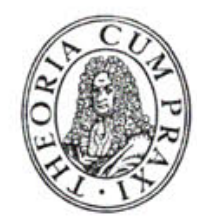

AKA DEMIE-VERLAG - BERLIN 
Subscriptions and orders for single copies should be directed in the DDR:

to the Postzeitungsvertrieb,

to a book-shop, or

to the Akademie-Verlag, DDR-108 Berlin, Leipziger Straße 3-4;

in the other socialist countries:

to a book-shop for foreign language literature or

to the competent news-distributing agency;

in the BRD and BERLIN (WEST):

to a book-shop or

to the wholesale distributing agency Kunst und Wissen, Erich Bieber, D-7000 Stuttgart 1, Wilhelmstr. 4-6;

in OSTERREICH:

to the Globus-Buchvertrieb, A-1201 Wien, Höchstädtplatz 3;

in the other Western European countries:

to Kunst und Wissen Erich Bieber GmbH, CH-8008 Zürich, Dufourstr. 51;

in USA and CANADA:

to Verlag Chemie International, Inc., 175 Fifth Avenue, New York, N.Y. 10010, USA;

in other countries:

to the international book- and journal-selling trade,

to Buchexport, Volkseigener Außenhandelsbetrieb der Deutschen Demokratischen Republik,

DDR-701 Leipzig, Postfach 160, or

to the Akademie-Verlag, DDR-108 Berlin, Leipziger Straße 3-4.

\section{Editorial Note:}

"physica status solidi (a)" undertakes that an original paper accepted for publication before the 23rd of any month will be published within $\mathbf{5 0}$ days of this date unless the author requests a postponement. In special cases there may be some delay between receipt and acceptance of a paper due to the review and, if necessary, revision of the paper.

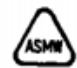

Schriftleiter und verantwortlich für den Inhalt:

Professor Dr. Dr. h. c. P. Görlich, DDR-102 Berlin, Neue Schönhauser Straße 20 bzw. DDR-69 Jena, Schillbachstraße 24. Verlag:

Akademie-Verlag, DDR-108 Berlin, Leipziger Straße 3-4; Fernruf 2236221 und 22362 29; Telex-Nr.: 114 420; Bank: Staatsbank der DDR, Berlin, Kto.-Nr.; 6836-26-20712.

Chefredakteur: Dr. H.-J. Hänsch.

Redaktionskollegium:

Prof. Dr. E. Gutsche, Dr. H.-J. Hänsch, Dr. H. Lange, Dr. S. Oberländer.

Anschrift der Redaktion:

DDR-102 Berlin, Neue Schönhauser Straße 20; Fernruf: 2823380.

Veröffentlicht unter der Lizenznummer 1620 des Presseamtes beim Vorsitzenden des Ministerrates der Deutschen

Demokratischen Republik.

Gesamtberstellung: VEB Druckerei „Thomas Müntzer“, DDR-582 Bad Langensalza.

Erscheinungsweise: Die Zeitschrift "physica status solidi (a)" erscheint jeweils am 16. eines jeden Monats. Jährlich erscheinen 6 Bände zu je 2 Heften.

Bezugspreis :

je Band 165,- M zuzüglich Versandspesen (Preis für die DDR: 130,- M).

Bestellnummer dieses Bandes: 1085/55

(C) 1979 by Akademie-Verlag Berlin.

Printed in the German Democratic Republic.

AN (EDV) 20735 